\title{
Ethnobotany of Okomu Forest Reserve, Edo State, Nigeria
}

\author{
UGBOGU, OA; *CHUKWUMA, EC \\ Forest Herbarium Ibadan (FHI), Forestry Research Institute of Nigeria, Jericho Hill, Ibadan. \\ *Corresponding Author Email: chukwumaemma@gmail.com
}

\begin{abstract}
An ethnobotanical survey of useful plants was conducted in Okomu forest reserve, with a view to documenting indigenous knowledge of medicinal plants used by the inhabitants of the communities and enclaves around the reserve. Information were obtainedfrom 106 structurally designed questionnaires, which were administered to different individuals and thereafter analysed using descriptive statistics. A total of 90 angiosperm species in belonging to 45 families were identified to be useful in the management of various ailments within the study area. Euphorbiaceae and the Legumes constituted the highest species occurrence while the largest number of plant families (22) had only one species each represented. Further findings showed that the leaves and stem bark are the most useful parts of the plants while the flower and pith were the least useful. In general, the trees were the most useful of all plant habits followed by the herbs and the shrubs. While this work reflects the biodiversity richness of the study area and its environs, it also suggests the enforcement of conservation strategies as a measure to mitigate species loss.
\end{abstract}

\section{DOI:https://dx.doi.org/10.4314/jasem.v23i7.31}

Copyright: Copyright (C) 2019Ugbogu and Chukwuma. This is an open access article distributed under the Creative Commons Attribution License (CCL), which permits unrestricted use, distribution, and reproduction in any medium, provided the original work is properly cited.

Dates: Received: 07 May 2018; Revised: 28 July2019; Accepted 30 July 2019

Keywords: Okomu Forest Reserve, ethno-medicine, medicinal plants, conservation

Herbal medicine is practised in many countries including Nigeria. A survey conducted in old Oyo State revealed that traditional medicine blends readily into the socio-cultural life of the people, in whose culture it is deeply rooted (Sofowora, 1993). Cunningham (1993) and WHO (2003) noted that the reliance on medicinal plants is partly owing to the high cost of modern drugs, inaccessibility of modern health institutions and due to cultural acceptability of the system. However, as time went on, the traditional knowledge about useful plants in many countries are gradually being depleted for reasons mainly attributed to environmental degradation and deforestation. Sood et al., (2001) also opined that a great deal of information about the traditional uses of plants is still intact with tribal peoples, but the native healers are often reluctant to accurately share their knowledge to outsiders. Another study by UNCTAD/Gatt (1974) had earlier shown that $60 \%$ of medicinal products are derived from plants (including microbes). Indeed, Nigeria has a great deal of flora diversity which are yet to be explored. Most Nigerian urban dwellers, due to changes imposed by modern life on social structures and attitudes, reject the efficacies of traditional medicine. However, Olapade and Bakare (1992) earlier noted that the prevailing economic recession in the country has forced large number of the populace to accepttraditional medicine because of the high cost of orthodox drugs. This has also increased the cost of herbal plants coupled with the high rate of deforestation, thereby making these plants almost unavailable. Okomu Forest Reserve is particularly rich in biodiversity. The wildlife sanctuary occupies the core of the reserve which was previously being managed by Nigerian Conversation Foundation (NCF), but now by the National Park Services. Fortunately, the Wildlife Sanctuary encloses the Permanent Sample Plot (PSP) of Forestry Research Institute of Nigeria (FRIN). The Wildlife Sanctuary is the safest part of the reserve at present because of mounting pressures by illegal timber extraction, the proposed Mitchelin Rubber Plantation, Iyayi Rubber Plantation and the Okomu Oil Palm Plantatiion on the remaining part of the reserve. This study centres on the ethnobotany of this important Forest Reserve with emphasis on ethno-medicine, as practiced by the communities around the Forest Reserve.

\section{MATERIALS AND METHODS}

Study area:The study area is located in Edo state and lies between latitude $6^{\circ} \mathrm{N}$ and $6^{\circ} 10^{\prime} \mathrm{N}$, and longitudes $5^{\circ} \mathrm{E}$ and $5^{\circ} 30^{\prime} \mathrm{E}$ (Figure 1). It is about $50 \mathrm{~km}$ West of Benin City and bounded by rivers Siluko and Osse to the west and east respectively. The region consists of a sandy coastal plain generally bellow $400 \mathrm{~m}$ above sea level (Udo, 1990, Soladoye et al., 1993). It is also characterized by tropical climate with a mean annual rainfall of about $2100 \mathrm{~mm}$, mean temperature of about 
$30.2^{\circ} \mathrm{C}$, and a high relative humidity which is less than $65 \%$ during the afternoon throughout the year (Soladoye et al., 1993).

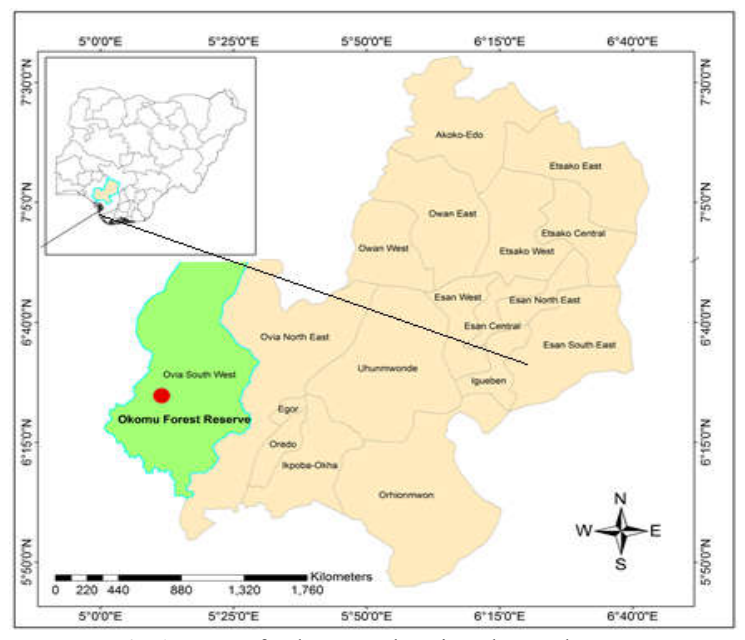

Fig 1. Map of Edo state showing the study area

Collection and identification of species: Fourteen out of twenty-four communities/enclaves were sampled for this study based on their proximity to Okomu Forest Reserve. These were Iguobauwa, Udo, Ofunama, A.T. \& P Camp, Siluko, Iguomwan, Irhuebor, Mile 3, Arakwan, Nikrowa, Ugbo, Etete, Ugolo, and Ikoka. Information were gathered with the aid of structurally designed questionnaires, to various individuals who are knowledgeable about the useful plants within the study area. The questionnaires were administered to a total of 106 respondents, through oral interview and their responses were carefully marked. Plants species reported were collected from the Permanent Sample Plot (PSP) of the Forestry Research Institute of Nigeria (FRIN), fallow farmland and Agroforestry Plots where other areas of research investigations were carried out during this study. Repeated visits were made to the communities/enclaves of the reserve, the first point of call being the head of each community/enclave around the reserve known as "Ojionwele". In most cases, the other community council members were intimated with the aims and objectives of our investigation before we went about the community interviewing different individuals with indigenous knowledge about medicinal plants and their uses, especially the elderly ones (Table 1).

The collected plants were also displayed to allow interested people of all ages to participate in our investigation. Nonetheless, all plant species were collected and identified at the Forest Herbarium Ibadan (FHI), listed in Holmgren et al., (1990). The information on the uses and local names of the plants were gathered and adequately presented in Table 2 .

Table 1. Summary of respondents according to their age groups

\begin{tabular}{llllll}
\hline \multicolumn{5}{c}{-} & \multicolumn{2}{l}{ Categories } \\
\hline Age groups & $\begin{array}{l}\text { Aged } \\
\text { couples }\end{array}$ & $\begin{array}{l}\text { Herbalists Herb } \\
\text { sellers }\end{array}$ & Others T otal \\
\hline $26-30$ & - & 1 & - & - & 1 \\
$31-35$ & - & - & 3 & 3 & 6 \\
$36-40$ & 1 & 2 & 6 & 4 & 13 \\
$41-45$ & 13 & 6 & 5 & 16 & 40 \\
45 and above & 22 & 9 & 13 & 2 & 46 \\
T otal & 36 & 18 & 27 & 25 & 106 \\
$\%$ & 34.0 & 17.0 & 25.5 & 23.6 & \\
\hline
\end{tabular}

\section{RESULTS AND DISCUSSION}

A total of 90 species belonging to 44 families were obtained from the survey. Only one family had 7 species, one had 5 species, four families had 4 species each, six families had 3 species each, eleven families had 2 species each, while the remaining twenty-two families had 1 species represented each. In general, Euphorbiaceae had the highest number of species represented $(7.8 \%)$, followed by Ceasalpinioideae (5.6\%). However, the Legumes (Caesalpinioideae, Mimosoideae and Papilionioideae) comprised 12.2\% of the total species (Table 3). The various uses of these plants and the parts used are shown in Figure 1 and 2 respectively. The medicinal uses scored highest with about $45 \%$, followed by fuel wood $37 \%$, while timber constituted $7 \%$. The leaves were mostly used and were readily available than other plant parts. The occurrence of plant habits in the four land used forms are also shown in Fig. 3. Generally, trees recorded the highest number of species, followed by herbs. Nonetheless, this does not necessarily mean that the population of trees is the highest in all the land used forms but this is in relation to the available ethnobotanical information. Further results on Figs 4 shows the percentage occurrence of the different plant habits in the land used types. This revealed that PSP had the highest number of trees, while shrubs were more in Agroforestry, and the herbs were the same for both Agroforestry and fallow land respectively. The implication of these results is that each of the land used types could meet the needs of the people without much pressure on the PSP. In reality, there was low ethnobotanical knowledge of plants that were strictly from PSP, though some of them were on sale and were mostly used by the full time herbalists.A total of 106 persons were interviewed (Table 1) and most of the respondents were above 45 years of age. The Aged couples constituted the highest number of the total respondents (34\%), while the herbalists had the least $(17 \%)$. This small number of herbalists is attributed to the fact that many of them require incentives before they can be willing to divulge useful information 
regarding the medicinal uses of these plants. The herb sellers in contrast were willing to provide some

information since they knew it will promote their trade.

Table 2. Some Plants Ethnobotanical Significance at Okomu Forest Reserve

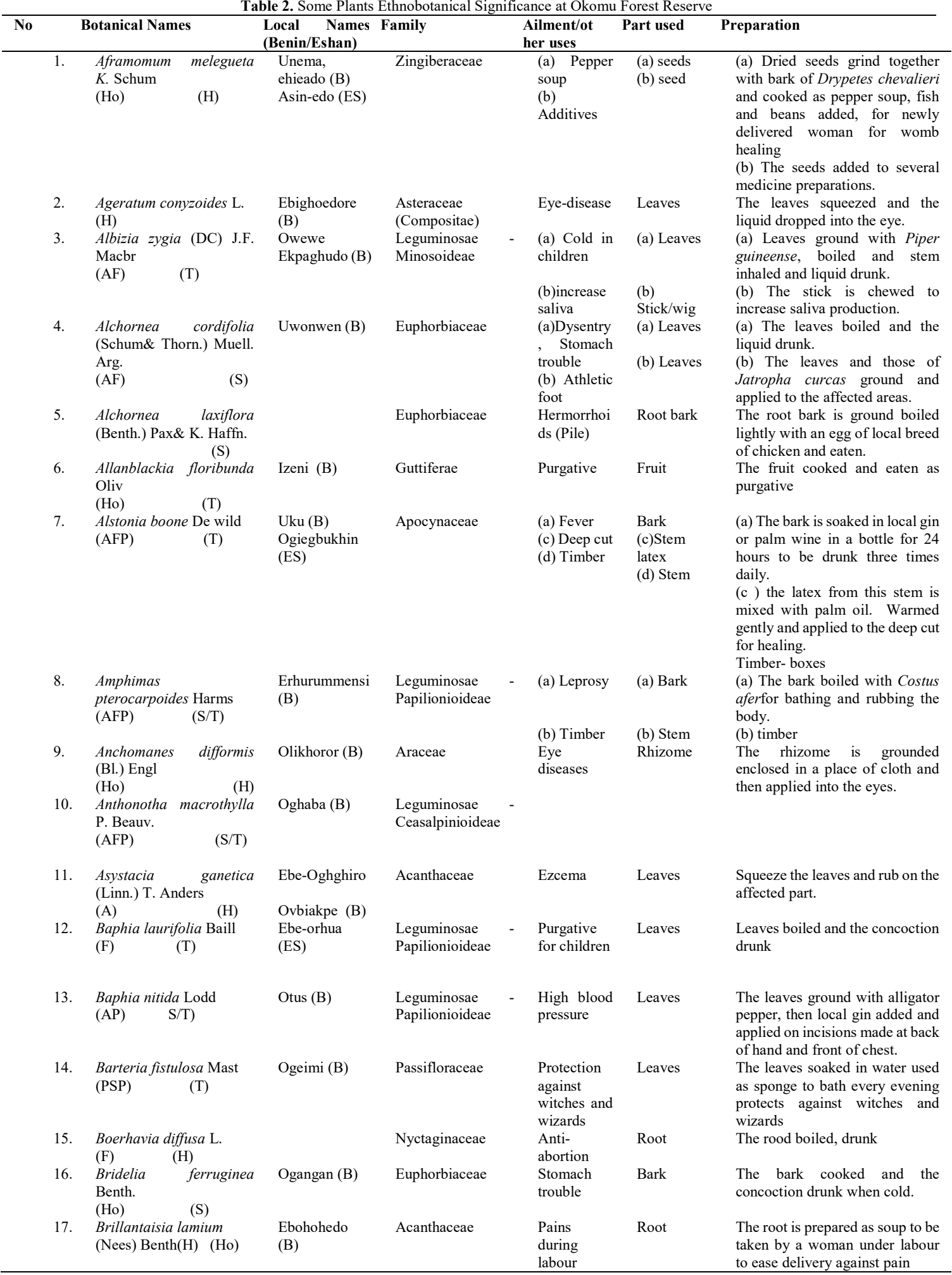


Ethnobotany of Okomu Forest Reserve.....1394

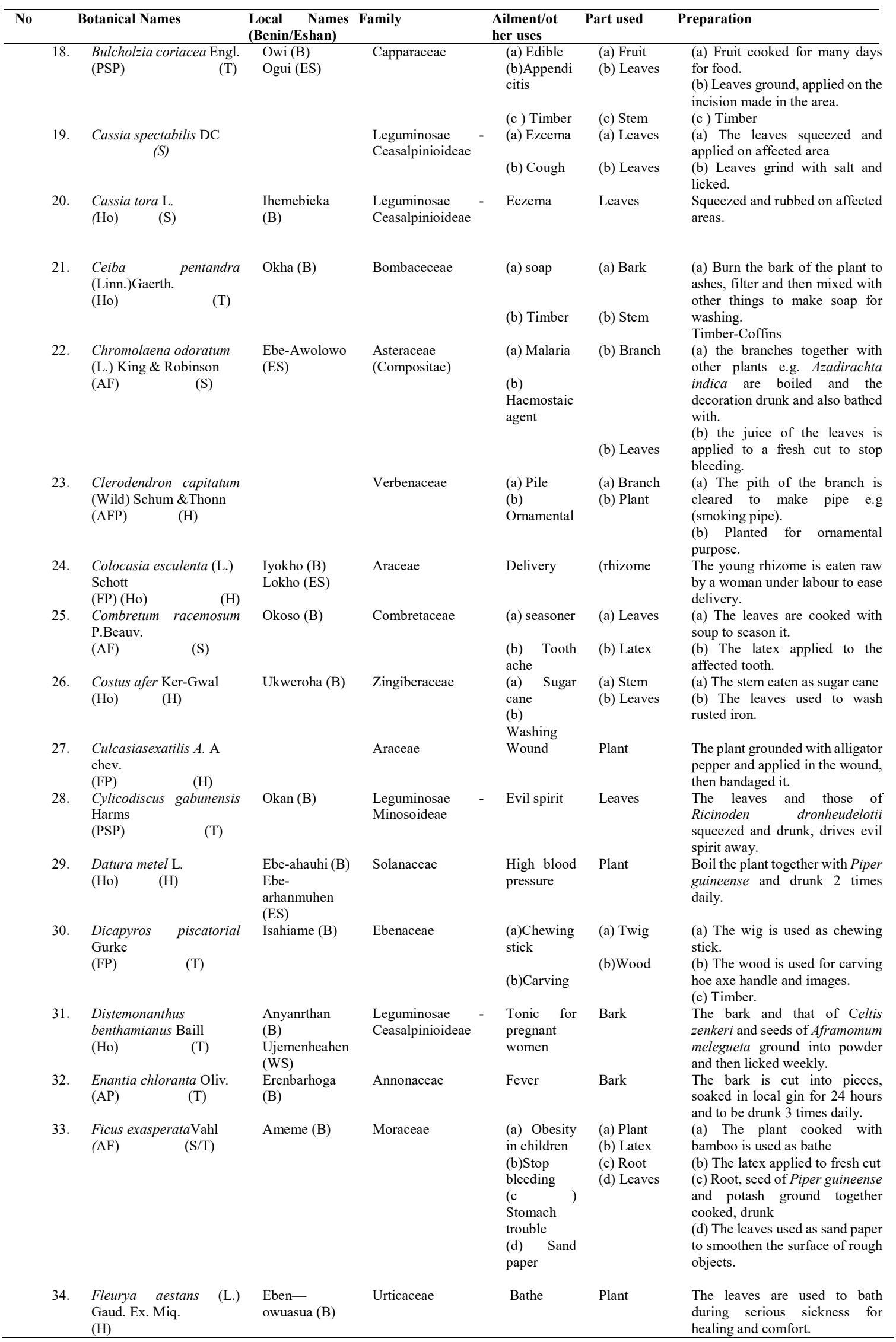


Ethnobotany of Okomu Forest Reserve.....1395

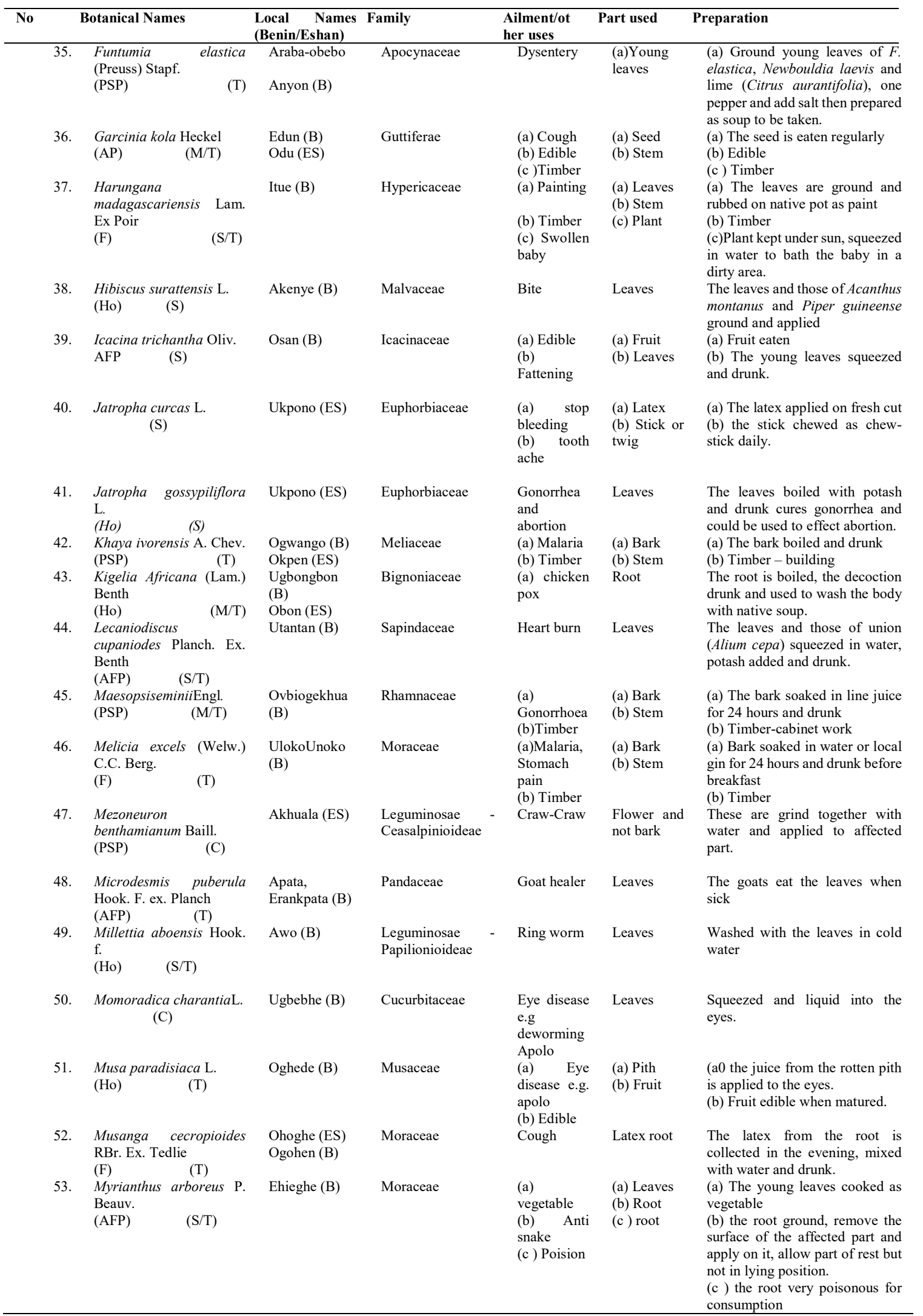


Ethnobotany of Okomu Forest Reserve.....1396

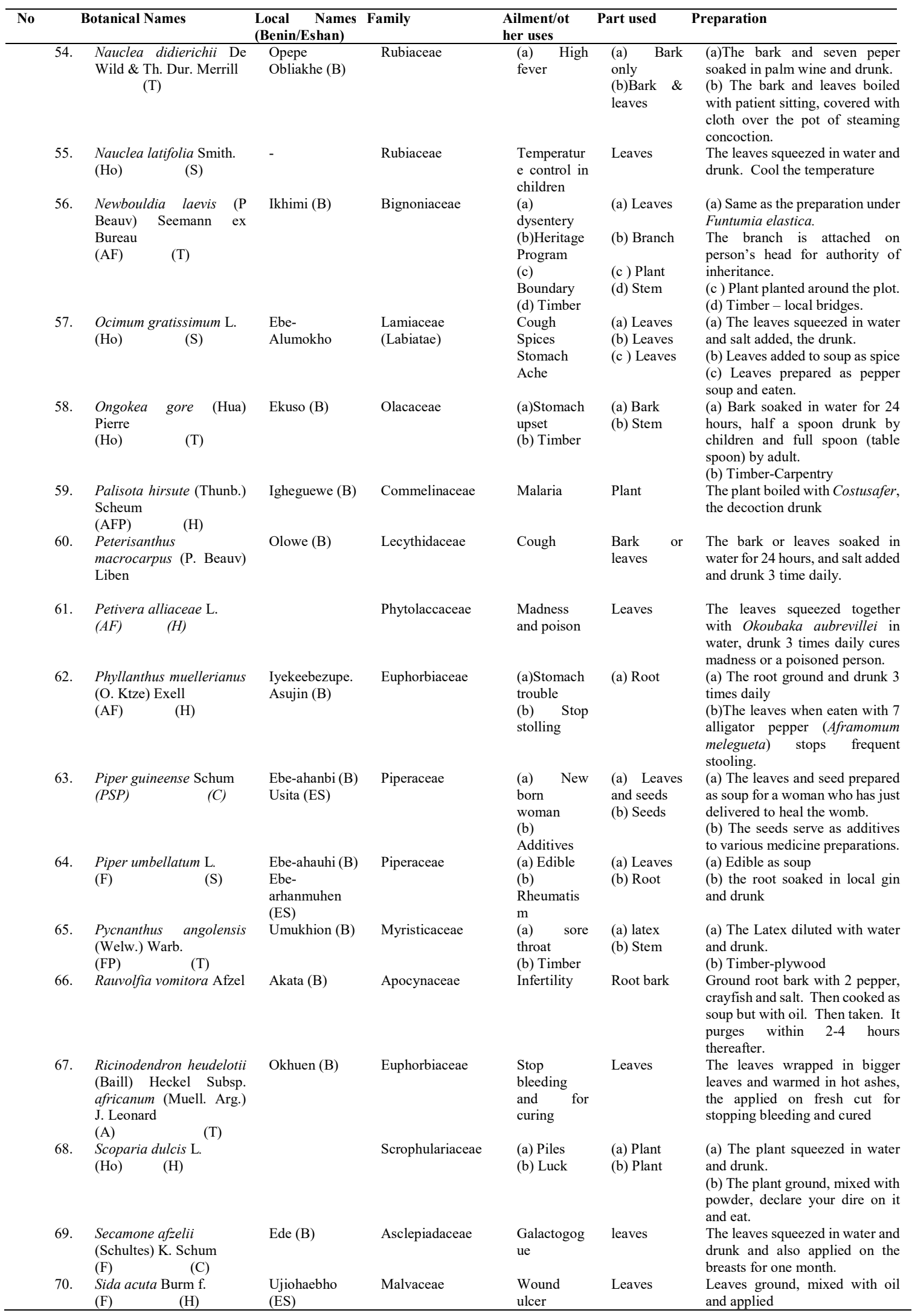


Ethnobotany of Okomu Forest Reserve.....1397

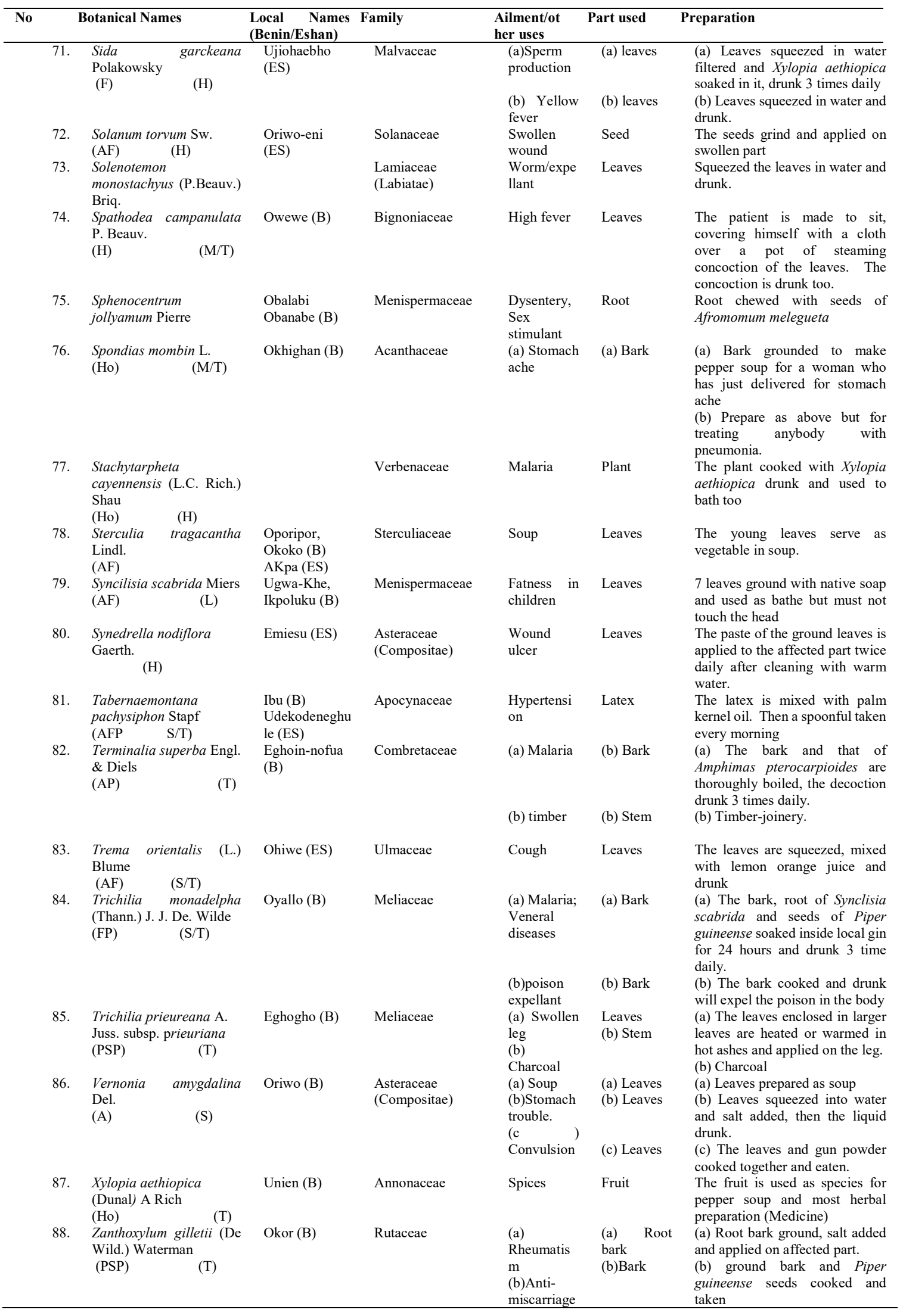


Ethnobotany of Okomu Forest Reserve.....1398

\begin{tabular}{|c|c|c|c|c|c|c|c|}
\hline No & & Botanical Names & $\begin{array}{l}\text { Local Names } \\
\text { (Benin/Eshan) }\end{array}$ & Family & $\begin{array}{l}\text { Ailment } / \text { ot } \\
\text { her uses }\end{array}$ & Part used & Preparation \\
\hline & 89. & $\begin{array}{l}\text { Zanthoxylum } \\
\text { zanthoxyloides (Lam.) } \\
\text { Zapern \&Timler } \\
\text { (Ho) }\end{array}$ & $\begin{array}{l}\text { Ugbanghan } \\
\text { (B) }\end{array}$ & Rutaceae & Infertility & Root bark & $\begin{array}{l}\text { The root bark grind with two } \\
\text { pepper and crayfish, salt added } \\
\text { and cooked but no oil, eaten. It } \\
\text { purges within } 2-4 \text { hours. }\end{array}$ \\
\hline & 90. & $\begin{array}{l}\text { Zingiber officinale Rocs. } \\
\text { (Ho) } \quad \text { (H) }\end{array}$ & & Zingiberaceae & Malaria & Leaves & $\begin{array}{l}\text { Used as additive in medicine } \\
\text { preparation for malaria. }\end{array}$ \\
\hline
\end{tabular}

Obviously, the Okomu Forest Reserve is a great economic asset to the Edo State Government, Ovia South West Local Government, some private entrepreneurs and the residents of the communities within and around the reserve. According to Famuyide et al., (1996), 63.33\% inhabitants affirmed that the forest is of immense benefit to the survival of the people. Benefits derived include food items, fuelwood, fruits, vegetable leaves, chewing sticks, medicinal plants etc. the monthly quantity estimates of four major products include fuelwood $(42.351 \mathrm{~kg})$, wildlife $(53,900 \mathrm{~kg})$, leaves $(2,798 \mathrm{~kg})$, snails (1452 units) and other food farm products amounting to $\$ 65,480.00$, $\$ 62,250.00, \$ 17,402.00, \$ 21,240.00$ and $\$ 3,788.68$ respectively. The yearly revenue generated from Okomu Forest Reserve by Edo State Government averaged to $\$ 6.2$ million during the 19990 - 1994 period.

The communities depended heavily on the traditional Health Care System since health centres existed in only 3 of the communities with highest population, viz: Udo, Igbuobazua and Siluko and these are far away from most of the communities. The medicinal plants were prepared in different formulations such as ointment, liquid preparations, powdered materials, infusion etc. Many of the plants listed in this study had earlier been reported also to be medicinally useful in other areas within the country. Some of such include the works of Gills (1992), Adesina et al., (1995) Okoli et al., (2007), Odugbemi (2008), Soladoye et al., (2010a,b), Ugbogu et al., (2010), Soladoye et al., (2012), Soladoye et al., (2014).

Further observations during the present study showed that the knowledge of medicinal plants for malaria, children's and pregnant women's ailments was very high and their preparations were readily available as first aid in nearly every home visited.

\begin{tabular}{|c|c|c|}
\hline Apocynaceae & 4 & 4.4 \\
\hline Araceae & 3 & 3.3 \\
\hline Asclepiadaceae & 1 & 1.1 \\
\hline Asteraceae (Compositae) & 4 & 4.4 \\
\hline Bignoniaceae & 3 & 3.3 \\
\hline Bombaceceae & 1 & 1.1 \\
\hline Capparaceae & 1 & 1.1 \\
\hline Combretaceae & 2 & 2.2 \\
\hline Commelinaceae & 1 & 1.1 \\
\hline Cucurbitaceae & 1 & 1.1 \\
\hline Ebenaceae & 1 & 1.1 \\
\hline Euphorbiaceae & 7 & 7.8 \\
\hline Guttiferae & 2 & 2.2 \\
\hline Hypericaceae & 1 & 1.1 \\
\hline Icacinaceae & 1 & 1.1 \\
\hline Lamiaceae (Labiatae) & 2 & 2.2 \\
\hline Lecythidaceae & 1 & 1.1 \\
\hline Leguminosae - Ceasalpinioideae & 5 & 5.6 \\
\hline Leguminosae - Mimosoideae & 2 & 2.2 \\
\hline Leguminosae - Papilionioideae & 4 & 4.4 \\
\hline Malvaceae & 3 & 3.3 \\
\hline Meliaceae & 3 & 3.3 \\
\hline Menispermaceae & 2 & 2.2 \\
\hline Moraceae & 4 & 4.4 \\
\hline Musaceae & 1 & 1.1 \\
\hline Myristicaceae & 1 & 1.1 \\
\hline Nyctaginaceae & 1 & 1.1 \\
\hline Olacaceae & 1 & 1.1 \\
\hline Pandaceae & 1 & 1.1 \\
\hline Passifloraceae & 1 & 1.1 \\
\hline Phytolaccaceae & 1 & 1.1 \\
\hline Piperaceae & 2 & 2.2 \\
\hline Rhamnaceae & 1 & 1.1 \\
\hline Rubiaceae & 2 & 2.2 \\
\hline Rutaceae & 2 & 2.2 \\
\hline Sapindaceae & 1 & 1.1 \\
\hline Scrophulariaceae & 1 & 1.1 \\
\hline Solanaceae & 2 & 2.2 \\
\hline Sterculiaceae & 1 & 1.1 \\
\hline Ulmaceae & 1 & 1.1 \\
\hline Urticaceae & 1 & 1.1 \\
\hline Verbenaceae & 2 & 2.2 \\
\hline Zingiberaceae & 3 & 3.3 \\
\hline
\end{tabular}

Table 4. Variety of uses of some plants of Okomu Forest Reserve

Table 3. Species occurrence within the plant families

\begin{tabular}{lll}
\multicolumn{2}{c}{ Table 3. Species occurrence within the plant families } \\
\hline Family & $\begin{array}{l}\text { Species } \\
\text { occurrence }\end{array}$ & $\begin{array}{l}\text { \% } \\
\text { occurrence }\end{array}$ \\
\hline Acanthaceae & 3 & 3.3 \\
Annonaceae & 2 & 2.2 \\
\hline
\end{tabular}

\begin{tabular}{ll}
\hline Uses & $\begin{array}{l}\text { No of Plants } \\
\text { recorded }\end{array}$ \\
\hline Timber & 16 \\
Carving & 1 \\
Fuel wood & 85 \\
Food (fruit, seed, spicesetc) & 12 \\
\hline
\end{tabular}




\begin{tabular}{ll}
\hline Gum & 2 \\
Soap & 3 \\
Medicinal & 105 \\
Cultural/Evil spirit control & 5 \\
Chewing stick & 1 \\
Painting & 1 \\
\hline
\end{tabular}

In fact, the frequency at which malaria preparations which are often prepared with local gin, are taken is alarming. The full time herbalists claimed that they have plant preparation for high blood pressure, infertility, impotence, epilepsy and lunacy but they would not divulge their knowledge to outsiders, even their children in most cases.

Table 5. Plant parts used in ethnobotany in Okomu Forest Reserve

\begin{tabular}{ll}
\hline Part (s) used & $\begin{array}{l}\text { No of cases } \\
\text { recorded }\end{array}$ \\
\hline Latex & 10 \\
\hline
\end{tabular}
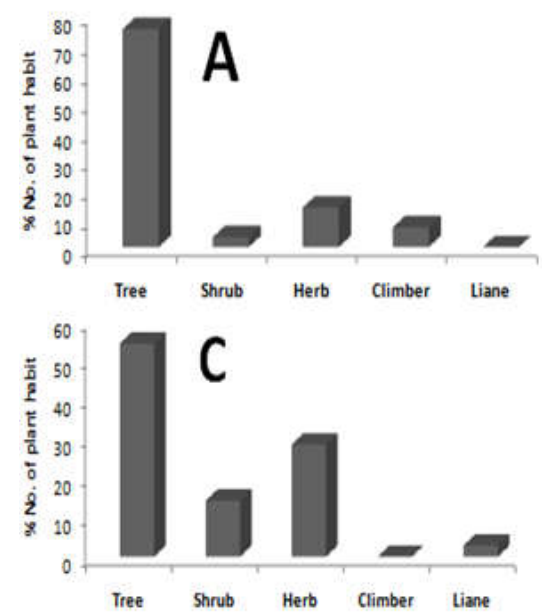

Fig 2. Percentage occurrence of plant habits in the various land use types. A - PSP; B -Agroforestry; C - Fallow; D - Homestead
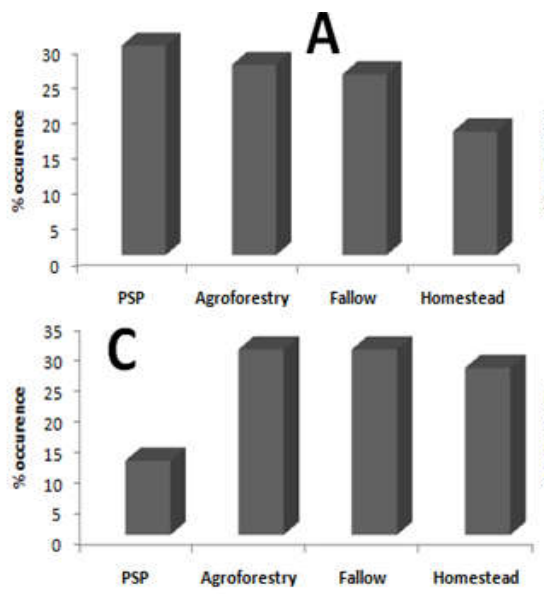

Fig2. Percentage occurrence of plant species in the various land use types. A - Trees; B - Shrubs; C - Herbs; D - Climbers \&lianes

Conclusion:There are many studies on medicinal plants scattered all over the country. The need to bring this work together is very urgent so that they can be
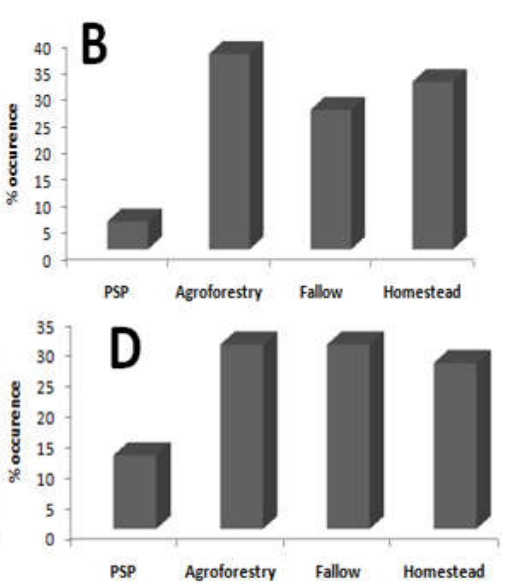

\begin{tabular}{ll}
\hline Leaves & 53 \\
Root & 13 \\
Fruit/seed & 12 \\
& \\
Bark & 20 \\
Rhizome & 2 \\
Whole plant & 11 \\
Twig/branch & 6 \\
Wood & 16 \\
Flower & 1 \\
Pith & 1 \\
Total & $\mathbf{1 4 5}$ \\
\hline
\end{tabular}

Table 6. Occurrence of plants in land use forms of Okomu forest reserve

\begin{tabular}{lllll}
\hline Plant habit & PSP & Agroforestry Fallow Homestead \\
Tree & 22 & 20 & 19 & 13 \\
Shrub & 1 & 7 & 5 & 6 \\
Herb & 4 & 10 & 10 & 9 \\
Climber & 2 & 1 & 0 & 0 \\
Liane? & 0 & 1 & 1 & 0 \\
Total & 29 & 39 & 35 & 28 \\
\hline
\end{tabular}
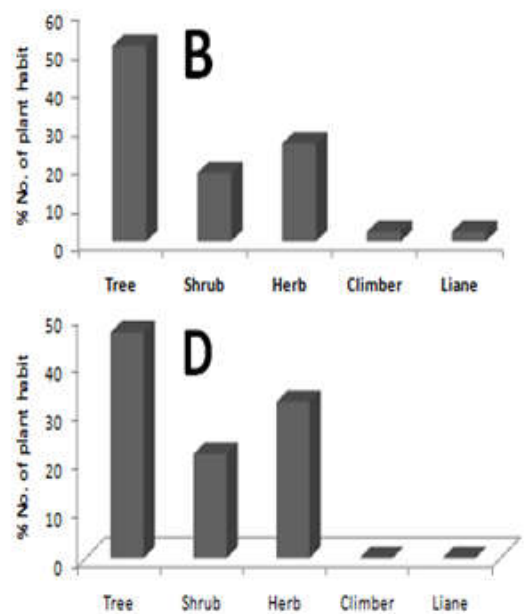

effectively co-ordinated for onward transfer for pharmacognostic analysis. Thus, findings from this study showed that Okomu Forest Reserve is very rich 
in medicinal plant species that has remained useful in the management of ailments since time immemorial, and hence, reflecting the richness of our tradomedicine flora. The need to conserve our forest is therefore very necessary, for we do not know which plants would cure the various dangerous diseases which are now ravaging the world especially Africa. There is also the need for co-operation and coordination of activities between the scientists and the traditional healers. At present, there is serious resentment of the scientist by the traditional healers, who claimed that scientists have exploited them over the years. However, the secrecy with which they carry out their practice is a long age tradition which can only be broken by winning their confidence.No doubt, there is a great threat to the future and sustainable management of Okomu Forest Reserve because of the dwindling financial resources available to government from other sources except from forestry. The Edo State Government needs to put a sustainable management plan on ground for Okomu Forest Reserve. Rational utilization should be encouraged. In fact, there is a great disillusion on the part of the residents of the communities about the seriousness of the State Government's determination at conserving Okomu Forest Reserve in view of her allocating vast estates to private entrepreneurs, consequently, some communities were being relocated from time to time. This situation should be arrested if Okomu Forest Reserve is not to be lost to posterity.

\section{REFERENCES}

Adesina, SK; Gbile, ZO; Odukoya, OA; Akinwusi, DD; Illoh, H.C; Yeola, AA (1995). Survey of indigenous useful plants of West Africa with special emphasis on medicinal plants and issue associated with their management. Pp. 84-85 in The United Nations Program on Natural Resources in Africa. Second edition. Institute for Natural Resources in Africa, Accra, Ghana.

Cunningham, AB (1993). African Medicinal Plants: Setting Priorities at the Interface between Conservation and Primary Health Care. People and Plants Working Paper 1.

Famuyide, OO; Agun, JO; Abu, JE (1996). Sociocultural and economic studies of Okomu Forest Reserve. In status Reports on Priority Research Projects of Forestry Research Institute of Nigeria, Vol. 2, pp. $107-131$.

Gills, LS (1992). Ethnomedical uses of plants in Nigeria. 276pp.Univ. Benin press, Nigeria.
Holmgren, P.K; Holmgren, NH; Barnett LC (eds.) (1990). Index Herbariorum - Part I: The Herbaria of the World (Regnum Veg. Vol. 120). New York Botanical Garden, New York.

Odugbemi, T (2008). A Textbook of Medicinal Plants from Nigeria. Unilag Press, Lagos, Nigeria.

Okoli, RI; Aigbe, O; Ohaju-Obodo, JO; Mensah, JK (2007). Medicinal herbs used for managing some common ailments among Esan people of Edo State, Nigeria. Pak. J.Nutr.6(5):490-496.

Olapade, EO; Bakare, OA (1992). Medicinal plants in Ibadan under Threats of Genetic Erosion: Proceedings of $22^{\text {nd }}$ Annual conferences of Forestry Association of Nigeria held in Kano, Kano State. $2^{\text {nd }}-7^{\text {th }}$ Nov. 1992, Pg. 54-59.

Sofowora, EA (1993). Medicinal Plants and Traditional Medicine in Africa. John Wiley and Sons Ltd, New York, New York.

Soladoye, MO; Chukwuma, EC; Owa, FP (2012). An 'Avalanche' of Plant Species for the Traditional cure of Diabetes mellitus in South-Western Nigeria. - J. Nat. Prod. Plant Resour; 2 (1): 60-72.

Soladoye, M. O; Adetayo, M. O; Chukwuma, E.C; Amusa, N.A (2010a). Ethnobotanical survey of plants used in the treatment of haemorrhoids in South-Western Nigeria. Annals Bio. Res.1(4):115 .

Soladoye, MO; Amusa, NA; Raji-Esan, SO; Chukwuma, EC; Ayanbamiji, AT (2010b). Ethnobotanical survey of anti-cancer plants in Ogun State, Nigeria. Annals Bio. Res. 1(4):261273.

Soladoye, MO; Chukwuma, EC; Sulaiman, OM; Feyisola, RT (2014). Ethnobotanical Survey of Plants Used in the Traditional Treatment of Female Infertility in Southwestern Nigeria. Ethnobot. Res. Appl. 12:081-090.

Soladoye, MO; Orhiere, SS; Ogunnusi, O (1993): Some Medicinal Plants of Okomu Wildlife Sanctuary in Edo State. In E.A. Oduwaiye (Ed) Forestry for Urban and Rural Development in Nigeria. Proceeding of the 23rd Annual Conference of the Forestry Association of Nigeria, Ikeja, Lagos State. Pp 226 - 239. 
Sood, SK; Nath, R; Kalia, DC (2001). Ethnobotany of Cold Desert Tribes of Lahoul-Spiti (N.W. Himalaya). Deep Publications, New Delhi.

Udo, KR (1990). Geography Regions of Nigeria. Heinemenn Educational Books Ltd. Ibadan, Nigeria, 210pp.

Ugbogu, AO; Ariwaodo, JO; Adeniji, KA (2010). An ethnomedicinal study of flora diversity in Osun sacred grove, Osun State, Nigeria. Int. J. Agri. Rural Dev. (4):186-196.
UNCTAD/Gatt (1974). Markets for selected medicinal plants and their derivatives. UNCTAD, Germany.

WHO (2003). Traditional Medicine: Fact Sheet No 134. 2003, Geneva, Switzerland: World Health Organization. 